\title{
Global soil-climate-biome diagram: linking surface soil properties to climate and biota
}

\author{
Xia Zhao ${ }^{1}$, Yuanhe Yang $^{1}$, Haihua Shen ${ }^{1}$, Xiaoqing Geng ${ }^{1}$, and Jingyun Fang ${ }^{1,2}$ \\ ${ }^{1}$ State Key Laboratory of Vegetation and Environmental Change, Institute of Botany, Chinese Academy of Sciences, \\ Beijing 100093, China \\ ${ }^{2}$ College of Urban and Environmental Sciences, and Key Laboratory for Earth Surface Processes of the Ministry of \\ Education, Peking University, Beijing 100871, China
}

Correspondence: Jingyun Fang (jyfang@urban.pku.edu.cn)

Received: 17 October 2018 - Discussion started: 29 January 2019

Revised: 16 June 2019 - Accepted: 28 June 2019 - Published: 25 July 2019

\begin{abstract}
Surface soils interact strongly with both climate and biota and provide fundamental ecosystem services that maintain food, climate and human security. However, the quantitative linkages between soil properties, climate and biota remain unclear at the global scale. By compiling a comprehensive global soil database, we mapped eight major soil properties (bulk density; clay, silt, and sand fractions; soil $\mathrm{pH}$; soil organic carbon, SOC, density; soil total nitrogen, STN, density; and soil $\mathrm{C}: \mathrm{N}$ mass ratios) in the surface soil layer $(0-30 \mathrm{~cm})$, based on machine learning algorithms, and demonstrated the quantitative linkages between surface soil properties, climate and biota at the global scale, which we call the global soil-climate-biome diagram. In the diagram, bulk density increased significantly with higher mean annual temperature (MAT) and lower mean annual precipitation (MAP); soil clay fraction increased significantly with higher MAT and MAP; soil pH decreased with higher MAP and lower MAT and the "critical MAP", which means the corresponding MAP at a soil $\mathrm{pH}$ of $=7.0$ (a shift from alkaline to acidic soil), decreased with lower MAT. SOC density and STN density were both jointly affected by MAT and MAP, showing an increase at lower MAT and a saturation towards higher MAP. Surface soil physical and chemical properties also showed remarkable variation across biomes. The soil-climate-biome diagram suggests shifts in soil properties under global climate and land cover change.
\end{abstract}

\section{Introduction}

As a critical component of the Earth system, soils influence many ecological processes that provide fundamental ecosystem services (Amundson et al., 2015; Milne et al., 2015; Adhikari and Hartemink, 2016). Soil physical properties, such as bulk density and soil texture, are important for water retention and the preservation of carbon (C) and nutrients (Hassink, 1997; Sposito et al., 1999; Castellano and Kaye, 2009; Stockmann et al., 2013; Jilling et al., 2018), whereas soil chemical properties, such as soil acidity $(\mathrm{pH})$, organic $\mathrm{C}$ and nutrient contents, are essential regulators of nutrient availability and plant growth, further affecting $\mathrm{C}$ and nutrient cycling as well as vegetation-climate feedbacks (Davidson and Janssens, 2006; Chapin III et al., 2009; Milne et al., 2015). As the most biogeochemically active soil layer, surface soil dominates the soil function and interacts strongly with climate and vegetation (Jenny, 1941; Alexander, 2013; Weil and Brady, 2016). Therefore, assessing the physical and chemical properties in surface soil could provide insights into global soil functions and support soil stewardship for securing sustainable ecosystem services (Batjes, 2009; Sanchez et al., 2009; Koch et al., 2013).

In the context of rapid environmental change, there is an increasing need for timely updated, high-quality and highresolution global mapping of soil properties (Grunwald et al., 2011). Based on the global database of soil properties (e.g., the Harmonized World Soil Database, HWSD), multiple linear regression models have been widely used for soil mapping (Batjes, 2009; Hengl et al., 2014). Although recent progress has been made by compiling larger numbers 
of soil profiles and performing accuracy assessments, the maps of global soil properties are subject to weak relationships between soil properties and the corresponding predictors (Hengl et al., 2014). Moreover, some attempts have been made to predict global soil properties based on Earth system models, but these predictions frequently showed a large variation among different models and agreed poorly with observational data (Todd-Brown et al., 2013; Tian et al., 2015). Recently, machine learning algorithms, such as random forest (RF) analyses have been successfully applied to develop spatially explicit estimates of soil organic C (SOC) (Grimm et al., 2008; Wiesmeier et al., 2011; Ding et al., 2016; Hengl et al., 2017). Compared with multiple linear regression models, RF analysis has several advantages, such as the ability to model nonlinear relationships, handle both categorical and continuous predictors, and resist overfitting and noise features (Breiman, 2001).

The underlying stability of soil systems is controlled by their inherent balance between mass inputs and losses, which strongly feeds back on climate and biota (Amundson et al., 2015; Weil and Brady, 2016). By overlapping the spatial distribution of climate types, biome types and soil orders, Rohli et al. (2015) first quantified the percentage of global land surface that is covered by the combinations of climate types, biomes and soil orders. However, quantitative linkages of soil properties, climate and biota have not yet been developed in a common diagram. Encouragingly, significant progress in digital soil mapping techniques and the rapidly growing quantity of recorded soil information (Sanchez et al., 2009; Grunwald et al., 2011; Arrouays et al., 2014; Hengl et al., 2014; Shangguan et al., 2014), provide a great opportunity to assess the quantitative linkages between soil properties, climate and biota at the global scale.

In this study, we first compiled a global soil database (GSD; see Sect. 2) that contains more than 28000 soil profiles for seven physical and chemical soil properties in the surface soil layer $(0-30 \mathrm{~cm})$, including bulk density $\left(\mathrm{g} \mathrm{cm}^{-3}\right)$; sand, silt, and clay fractions $(\%)$; soil $\mathrm{pH}$; SOC density $\left(\mathrm{kg} \mathrm{m}^{-2}\right)$; and soil total nitrogen (STN) density $\left(\mathrm{kg} \mathrm{m}^{-2}\right)$. Using regional $\mathrm{RF}$ algorithms, we then established global soil maps for eight soil properties (the abovementioned seven soil properties plus $\mathrm{C}: \mathrm{N}$ ratios, being estimated based on SOC density and STN density) at a $1 \mathrm{~km}$ resolution and evaluated their corresponding uncertainties. On the basis of the Whittaker biome diagram, which illustrates the essential role of climate in shaping the spatial pattern of global biomes (Whittaker, 1962), we further developed a global soil-climate-biome diagram by plotting each soil property on a climate basis, as climate and vegetation are two key soil-forming factors (Jenny, 1941). Although parent material (e.g., bedrock) also plays an important role in affecting soil properties, it affects soil formation on a relatively long timescale (Chesworth, 1973), particularly in the subsoil (Gentsch et al., 2018). In addition, our soil-climate-biome diagram thus focuses on soil properties in the surface layer, given that surface soils are dynamic in time and likely interacting instantly with climate and vegetation than deeper soils (Weil et al., 2016). Overall, our objectives were to (i) map the physical and chemical properties of global surface soils and (ii) determine the linkages between surface soil properties, climate and biota at the global scale.

\section{Materials and methods}

\subsection{Dataset}

We compiled ground-truth soil property data to establish a comprehensive database of worldwide soil profile information (global soil database, GSD). Our GSD includes existing sources of soil profile data from the International Soil Reference and Information Centre World Inventory of Soil Emission (ISRIC-WISE) Potential database (version 3.2; Batjes, 2009), soil reference profiles of Canada (Pan et al., 2011), land resources of Russia from the International Institute for Applied Systems Analysis (IIASA) (http://nsidc.org/data/ ggd601.html, last access: 18 July 2019), the International Soil Carbon Network (ISCN 2012, https://iscn.fluxdata.org/ data/dataset-information/data-documentation/, last access: 2 February 2017), the Soil Profile Analytical Database of Europe (SPADE), the Northern Circumpolar Soil Carbon Database (NCSCD, Tarnocai et al., 2009), the Second State Soil Survey of China (National Soil Survey Office, 1995, 1998), literature-retrieved soil data on the forests of China (Yang et al., 2014), field campaign data on the grasslands of northern China (from our research team; Yang et al., 2008, 2010) and field survey data of Australia (Wynn et al., 2006) (see Table S1 in the Supplement for more detailed information on these data sources). Overall, the GSD includes more than 28000 soil profiles (Fig. 1; Table S1). Although the total sample number and spatial distribution of the profile data are similar to those of the WISE30sec (Batjes, 2016), the GSD includes more specific soil data from China. Nonetheless, both databases include limited profiles for some regions of the world, notably Australia, Sahara, and the northern territories of both Canada and Russia (Fig. 1).

The GSD includes field-measured data of four physical soil properties (bulk density $\left[\mathrm{g} \mathrm{cm}^{-3}\right.$ ] and sand, silt and clay fractions [\%]), three chemical soil properties (soil pH, SOC density $\left[\mathrm{kg} \mathrm{C} \mathrm{m}^{-2}\right]$ and STN density $\left.\left[\mathrm{kg} \mathrm{N} \mathrm{m}^{-2}\right]\right)$ in the surface soil layer (see Table S2 and Fig. S1 in the Supplement for more details) and general information on soil sampling (site location, sampling time and data source). Data harmonization was conducted in three steps. First, we screened sampling and measurement approaches of each soil property and excluded those data that were not comparable to others in methodology. For instance, geographic-coordinate data were included only when World Geodetic System, 1984 (WGS84), or a geographic-coordinate system that could be converted to WGS84 projection was used; soil texture data were included 


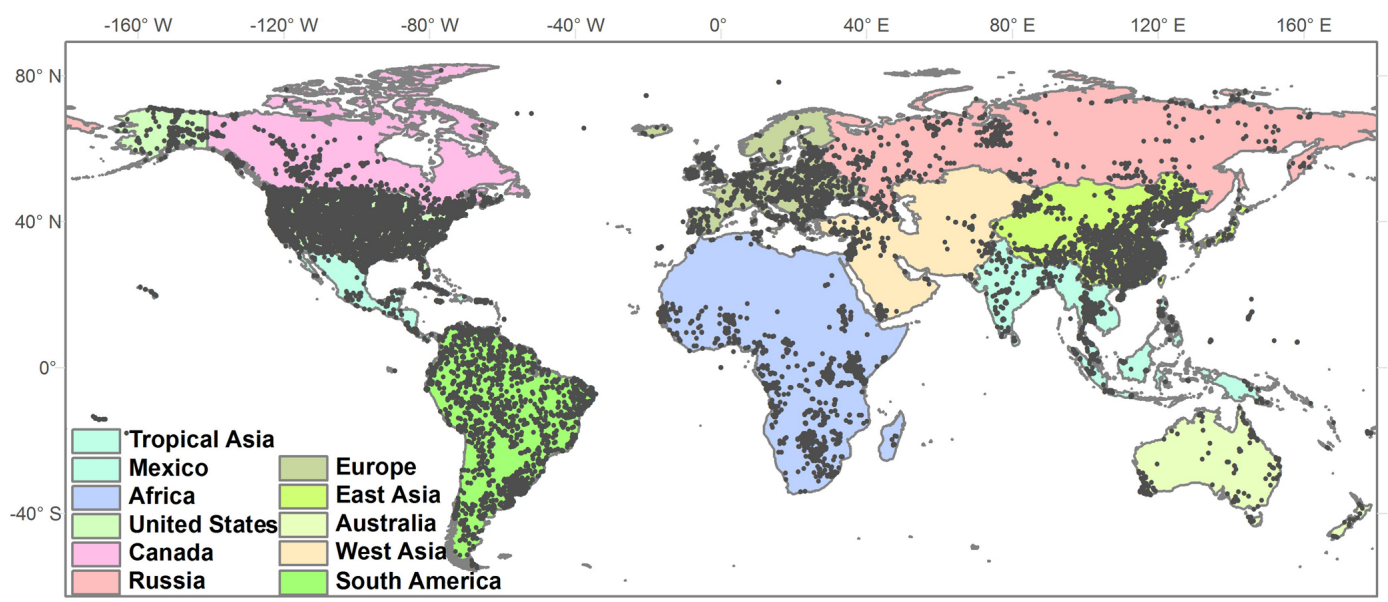

Figure 1. Global distribution of 28222 soil profiles included in the global soil database (GSD).

only when the internationally accepted particle size class was used (clay $<2 \mu \mathrm{m}<$ silt $<50 \mu \mathrm{m}<$ sand $<2000 \mu \mathrm{m}$ ). This allowed us to construct a database of soil properties with comparable methodology. Second, we excluded records with no information on the target soil depth $(0-30 \mathrm{~cm})$. In the case that soil organic matter was measured instead of SOC, we used a Bemmelen index (0.58) to convert soil organic matter into SOC. If data of bulk density were not provided, we estimated them based on region-specific pedotransfer functions (Schaap and Leij, 1998; Yang et al., 2007; Abdelbaki, 2018) (Table S3). Specifically, we established an empirical relationship between bulk density and SOC content to estimate bulk density based on measured SOC for those cases with missing data of bulk density. There was a total of $42 \%$ of profiles with measured data of bulk density and $58 \%$ of profiles with estimated data of bulk density. It is true that the correction for rock fragment is important for the estimation of soil C stocks, but it remains a global challenge because existing databases usually contain limited information on gravel fractions (Jandl et al., 2014). Nevertheless, the inclusion of gravel has been shown to exert a relatively low impact on the calculation of SOC stocks in the surface soil layer $(0-30 \mathrm{~cm})$, mainly due to the fact that surface soil usually contains a low proportion of gravels (Saiz et al., 2012). Therefore, we assumed no rock fragment or the rock issue had been handled once it was not reported. Finally, we extracted data on soil properties of the $0-30 \mathrm{~cm}$ soil depth and calculated the means of each soil property. SOC (STN) density was calculated based on bulk density and SOC (STN) content.

The GSD also contains pedologic information on soil orders and the horizons of the sampled soil profiles, mean annual temperature (MAT), mean annual precipitation (MAP), seasonality of air temperature (TS, calculated as $100 \times$ $\mathrm{SD}_{\text {monthly }} / \mathrm{Mean}_{\text {monthly }}$ ) (Xu and Hutchinson, 2011), seasonality of precipitation (PS), mean annual normalized difference vegetation index (NDVI), elevation (global digital elevation map, DEM), slope, and land use type for each recorded site (see Table S4 for more details). Notably, it was difficult to harmonize data of soil orders and further quantify their roles because data on soil orders were originally reported based on several different soil classification systems with different standards (Carter and Bentley, 2016). It was the same case for soil horizon. Additionally, horizon information was not reported in some cases (accounting for $15 \%$ profile), while soil depth was well-documented in our database. Therefore, we were not able to consider the role of soil horizons and instead we simply estimated the mean soil properties by a fixed depth of $30 \mathrm{~cm}$. Nevertheless, the depth of $0-30 \mathrm{~cm}$ has been frequently used in the mapping and modeling of surface soil properties at regional and global scales (e.g., Batjes, 1997; Yang et al., 2010; Saiz et al., 2012; Wieder et al., 2013; Shangguan et al., 2014). As $96 \%$ of soil profiles in GSD were sampled from 1950 to 2000, we thus used multiple-year (1950-2010) averages of climatic variables from the WorldClim database. For sites with missing reports on climate or topographical data, profile coordinates were used to derive data at each site using a selection of GIS layers from the WorldClim database for MAT and MAP and GTOP30 DEM-derived surfaces.

\subsection{Region-specific random forest model}

The random forest (RF) model is a data-mining algorithm for making predictions based on an ensemble of randomized classification and regression trees (Breiman, 2001). We mapped soil properties based on a region-specific RF approach that yields spatially explicit estimates of each pixel (see Fig. S2 for more details on the workflow of this approach). To overcome spatial biases of the database (for example, heavy sampling in the USA), we divided the global land into 11 regions: Africa, Australia, Canada and Alaska, East Asia, Europe, Mexico, Russia, South America, tropical Asia, the USA and West Asia (Table S2). In each region, we first constructed a RF model using the regional 
datasets and then used the model to estimate the spatial distribution of each soil property at a resolution of $1 \mathrm{~km}$. Predictions were based on eight environmental variables, including MAT, MAP, TS, PS, vegetation cover conditions (NDVI), elevation, slope and land use type (see Table S4 for more details on the data sources of each variable). To obtain a robust variogram, soil property data below the $2.5 \%$ quantile and above the $97.5 \%$ quantile were excluded as outliers and were not used for modeling in each region (Pleijsier, 1989; Jiménez-Muñoz et al., 2015). Notably, these excluded samples were distributed relatively randomly in space (Fig. S3). By conducting an analysis using all data samples and comparing the results with those excluding outliers, we found similar spatial patterns and means of global surface soil properties (Figs. 2 and S4) but lower cross-validated $R^{2}$ when including all samples (Tables S5 and S6). This implies an improvement of prediction by excluding outlier samples.

Because a large number of regression trees are constructed, one major advantage of RF model is that the risk of overfitting can be reduced. Another advantage is that the prediction depends on only three user-defined parameters: the number of trees (ntree), the minimum number of data points at each terminal node (nodesize) and the number of features sampled for splitting at each node (mtry). We used ntree $=1000$ (default ntree $=500$ ) in order to achieve more stable results (Grimm et al., 2008). For nodesize and mtry, we used the default set for RF regression. Also called a "black box" approach, one major disadvantage of RF model is that the relationships between the response and predictor variables cannot be interpreted individually for every RF tree. The relative importance of variables, denoted by the percent increase in mean-square error (\%IncMSE), was estimated based on a permuting out-of-bag (OOB) method (Strobl et al., 2009a, b). For each tree of the random forest, we compared the prediction error on the OOB portion of the data (MSE for regression) with that after permuting each predictor variable. The differences were then averaged over all trees and normalized by the standard deviation of the differences. The relative percent (mean / SD) increase in MSE as compared to the out-of-bag rate (with all variables intact) was used to indicate the relative importance of each variable (Breiman, 2001).

\subsection{Uncertainty analysis}

In each region, we used 10-fold cross-validation to estimate the average mapping accuracy for each target soil property. The modeling accuracy for each bootstrap sample was evaluated by the amount of variation explained by the models $\left(R^{2}\right)$ and by the root-mean-square error (RMSE), calculated based on the observational and predicted soil property in the independent validation dataset (Table S5). Model uncertainties were assessed based on the bootstrap method. A robust estimate was derived by averaging the 10 -fold cross-validation samples, and the uncertainty of the estimates was calculated as the standard deviation (SD) of the 10-fold cross-validation (Fig. S4).

\subsection{Statistical analysis}

Based on the results of the ensemble models, we mapped each soil property (bulk density, sand, silt, clay, $\mathrm{pH}$, SOC density and STN density) and their uncertainty at a resolution of $1 \mathrm{~km}$. Soil $\mathrm{C}: \mathrm{N}$ ratios were mapped based on values of SOCD and STND, and its uncertainty could be jointly indicated by the uncertainties of SOCD and STND. We also plotted each soil property on a modified Whittaker biome diagram. To explore the roles of MAT and MAP, as well as their interactions, we averaged soil property values for each MAT $\times$ MAP combination by a division of $1{ }^{\circ} \mathrm{C} \times 100 \mathrm{~mm}$ and explored quantitative linkages between soil properties and climate variables (MAT and MAP) for different climate types (humid vs. arid; warm vs. cold). Specifically, we used a MAP threshold of $500 \mathrm{~mm}$ to differentiate relatively humid vs. arid climates (Holdridge, 1967), while a MAT threshold of $10^{\circ} \mathrm{C}$ was used to separate relatively warm and cold climates (Trewartha and Horn, 1980). To explore the role of MAT in regulating the critical MAP for a shift from alkaline to acidic soil, we further plotted the critical levels of MAP ( $100 \mathrm{~mm}$ division) at soil $\mathrm{pH}=7.0$ with MAT. We then compared the soil properties across the main biomes, including tropical forest, temperate forest, boreal forest, tropical savannahs and grasslands, temperate grasslands and shrublands, tundra, permanent wetlands, deserts and croplands. All statistical analyses were performed using MATLAB 2015a (The MathWorks Inc., Natick, MA, USA). Values were presented as mean \pm standard deviations if not specially noted.

\section{Results}

\subsection{Global mapping of soil properties}

Our results agreed well with the observed data across most regions (Fig. S5), and the ensemble models generally explained $30 \%-60 \%$ of the variation in soil properties (Table S5). The eight soil properties showed great spatial heterogeneity across the globe in the upper $30 \mathrm{~cm}$ layer (Fig. 2). For instance, bulk density showed low values in the northern latitudes of the Eurasian continent, whereas high values occurred in the USA, North Africa, West Asia and India (Fig. 2a). The clay fraction exhibited lower values at higher latitudes, whereas higher levels of sand fraction occurred at lower latitudes (Fig. 2b, c). The pH value of the surface soil was high (generally $>7.0$ ) in arid regions and it was relatively low (generally $<6.0$ ) in most forested regions (Fig. 2e). The spatial patterns of SOC density and STN density were generally similar, both showing greater values at higher latitudes in the Northern Hemisphere and no consistent change with latitude in the Southern Hemisphere (Fig. 2f, g). Specifically, SOCD and STND both showed the 
(a)

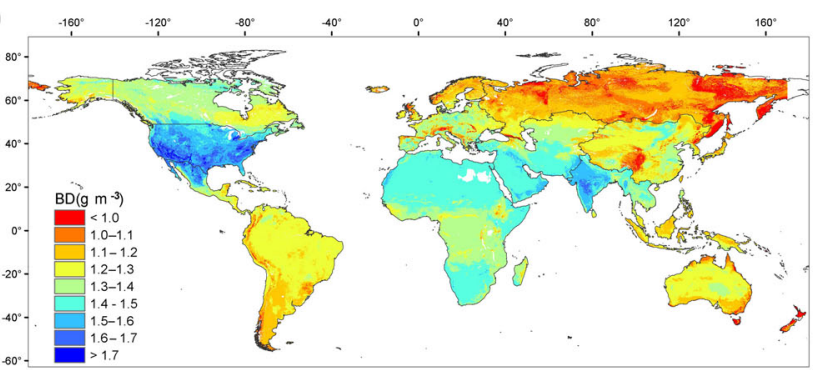

(c)

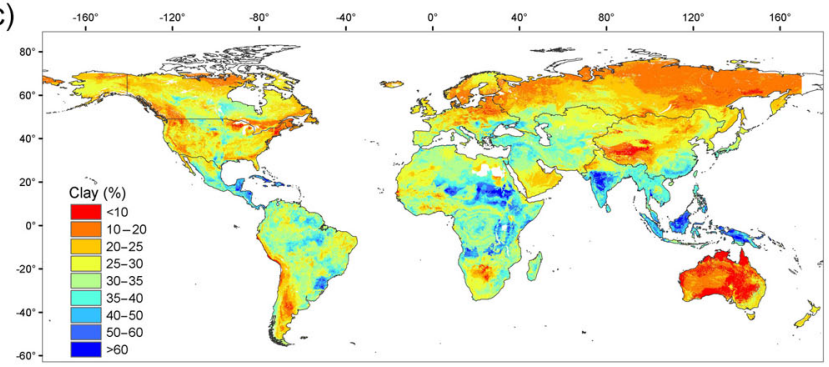

(e)

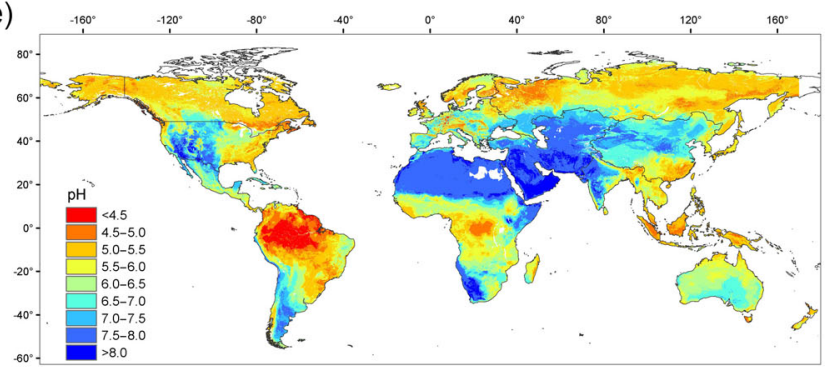

(g)

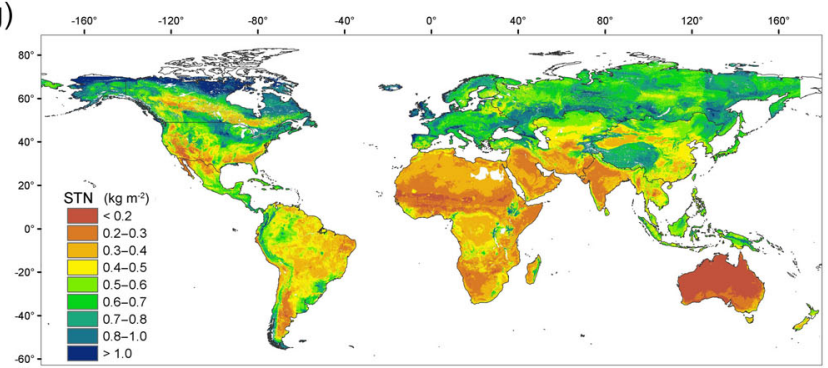

(b)

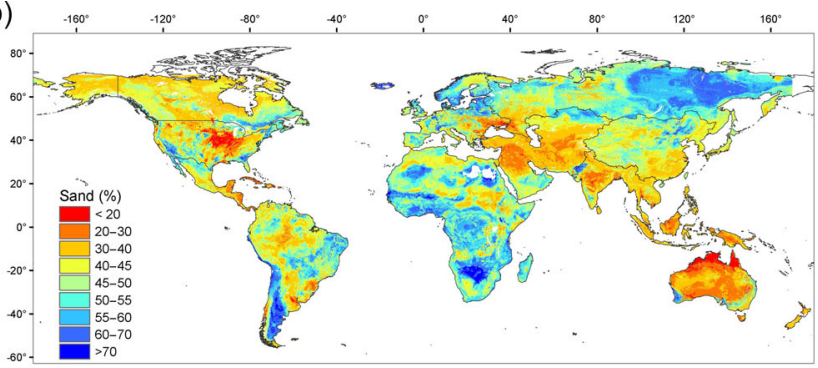

(d)

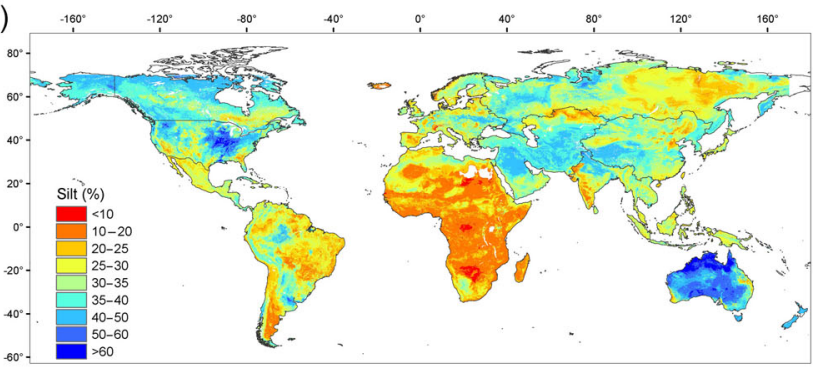

(f)

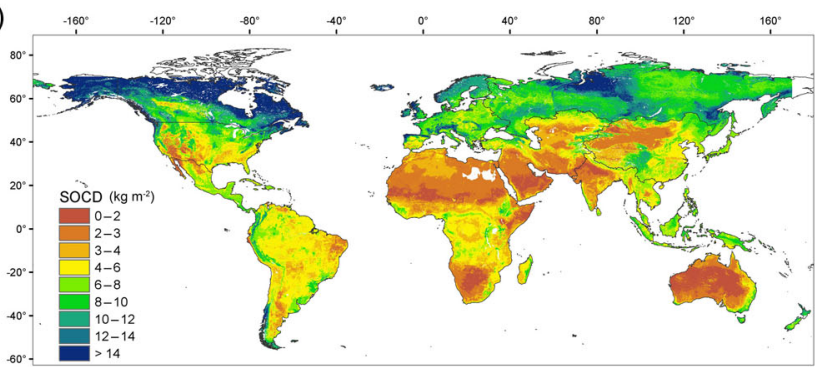

(h)

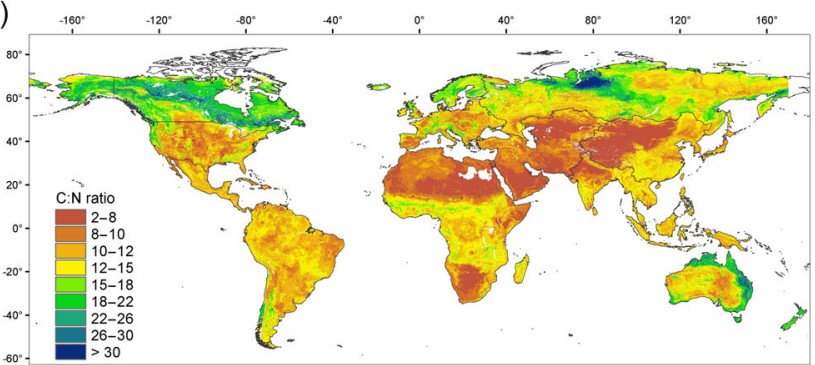

Figure 2. Maps of surface $(0-30 \mathrm{~cm})$ soil properties. (a) BD (bulk density, $\left.\mathrm{g} \mathrm{m}^{-3}\right)$, (b) sand fraction (\%), (c) silt fraction (\%), (d) clay fraction (\%), (e) $\mathrm{pH}$, (f) SOCD (soil organic carbon density, $\mathrm{kg} \mathrm{m}^{-2}$ ), (g) STND (soil total nitrogen density, $\mathrm{kg} \mathrm{m}^{-2}$ ) and (h) $\mathrm{C}: \mathrm{N}$ ratio.

highest values in the northern high latitudes, while low values occurred in semiarid and desert regions. Soil $\mathrm{C}: \mathrm{N}$ ratio showed the highest values at high latitudes in the Northern Hemisphere, while the lowest values occurred in arid regions in Northern Africa, West Asia and Southern Europe (Fig. 2h).

\subsection{Global soil-climate-biome diagram}

By placing data of surface soil properties on the Whittaker climate-biome diagram (Whittaker, 1962), we then documented the linkages between soil properties and climate across global biomes. We call this the global soil-climatebiome diagram (Fig. 3). Specifically, bulk density decreased with lower MAT and higher MAP (Figs. 3a, 4a, b); sand fraction was inversely related to MAP and MAT (Figs. 3b, $4 \mathrm{c}, \mathrm{d})$, whereas the clay fraction showed an opposite pattern (Figs. 3c, 4e, f); and soil pH increased with higher MAT in arid climate (MAT $\leq 500 \mathrm{~mm}$ ) (Figs. 3e, 5a), while it decreased significantly with higher MAP both in cold climates (MAT $\leq 10^{\circ} \mathrm{C}$ ) and warm $\left(\mathrm{MAT}>10^{\circ} \mathrm{C}\right.$ ) climates (Figs. 3e, 5b). The critical MAP for the transition from alkaline to acidic soil $(\mathrm{pH}=7.0)$ showed a nonlinear increase with MAT and reached a maximum of $400-500 \mathrm{~mm}$ when MAT exceeded $10{ }^{\circ} \mathrm{C}$ (Fig. 5c). 
(a)

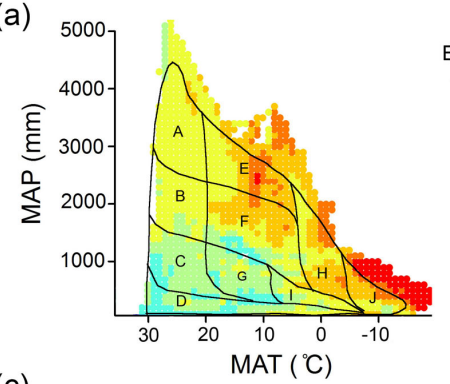

(c)

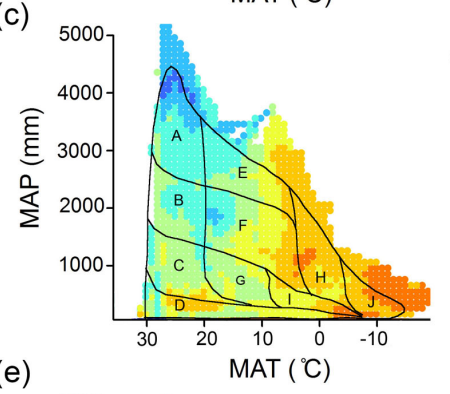

(e)

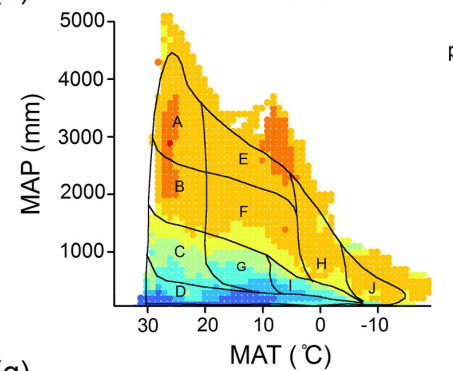

(g)

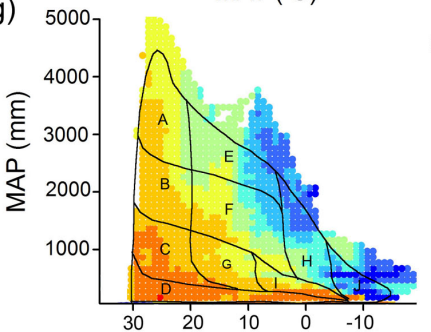

(b)

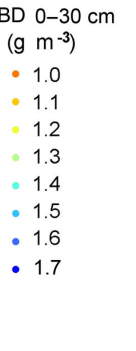

(d)

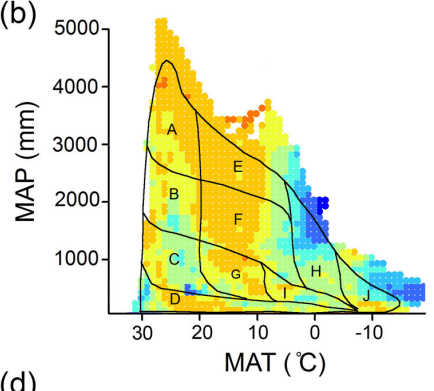

Sand $0-30 \mathrm{~cm}$

(\%)

- 20

- 30

40

45
-50

55

- 55

- 70

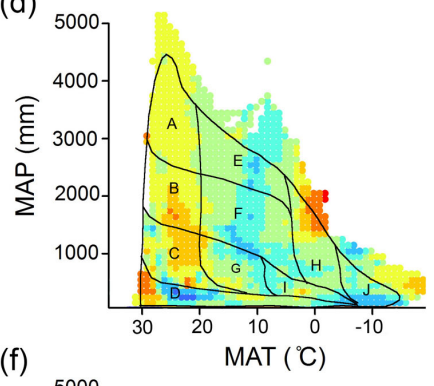

Silt 0-30 cm

Clay 0-30 cm

(\%)

- 10

- 15

20
-25

- 30

- 35

- 40

- 50

(f)

pH 0-30 cm

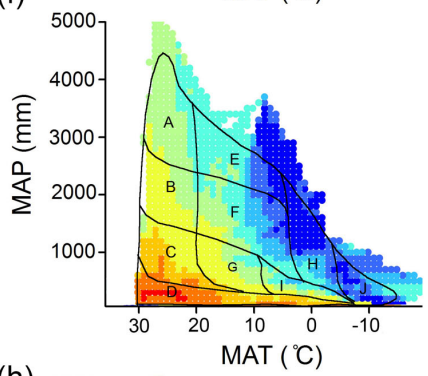

SOCD 0-30 cm

$\left(\mathrm{kg} \mathrm{m}^{-2}\right)$

- 2

- 3

4.5
5.0

5.0
$-\quad 5.5$

6.0
6.5

- 6.5

- 7.0

- 7.5

- 8.0

STND 0-30 cm

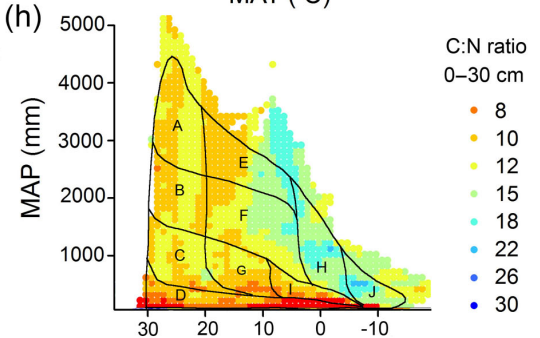

Figure 3. Changes in surface $\left(0-30 \mathrm{~m}\right.$ ) soil properties on the Whittaker biome diagram. (a) BD (bulk density, $\mathrm{g} \mathrm{m}^{-3}$ ), (b) sand fraction (\%), (c) silt fraction (\%), (d) clay fraction (\%), (e) $\mathrm{pH}$, (f) SOCD (soil organic carbon density, $\mathrm{kg} \mathrm{m}^{-2}$ ), (g) STND (soil total nitrogen density, $\mathrm{kg} \mathrm{m}^{-2}$ ) and (h) $\mathrm{C}: \mathrm{N}$ ratio. Each square shows the average value of soil properties within each $1^{\circ} \mathrm{C}$ of MAT and $100 \mathrm{~mm}$ of MAP. Each biome type in the modified Whittaker biome diagram is indicated by a capital letter. A: Tropical rainforest; B: Tropical seasonal forest; C: Tropical thorn scrub and woodland; D: Desert; E: Temperate rainforest; F: Temperate forest; G: Savanna; H: Boreal forest; I: Grassland; J: Tundra.

SOC density in the upper $30 \mathrm{~cm}$ soil layer decreased significantly with MAT in both arid (MAT $\leq 500 \mathrm{~mm}$ ) and humid climates (MAT $>500 \mathrm{~mm}$ ) (Fig. 3f), whereas it increased with MAP in accordance with a saturation curve (cold climate: $\mathrm{MAT} \leq 10^{\circ} \mathrm{C}: \mathrm{SOCD}=0.0737 \times \mathrm{MAP} /(1+$ $0.0049 \times \mathrm{MAP})$; warm climate: $\mathrm{MAT}>10^{\circ} \mathrm{C}: \mathrm{SOCD}=$ $0.0144 \times \mathrm{MAP} /(1+0.0016 \times \mathrm{MAP}))$, showing a higher saturation threshold in cold climates $\left(14.5 \mathrm{~kg} \mathrm{C} \mathrm{m}^{-2}\right)$ compared to warm climates $\left(8.0 \mathrm{~kg} \mathrm{C} \mathrm{m}^{-2}\right)$ (Fig. 6b). Similarly, STN density decreased significantly with MAT (Fig. 6c) and increased with MAP in accordance with a saturation curve (cold climate: $\mathrm{STN}=0.0401 \times \mathrm{MAP} /(1+0.0502 \times$ MAP); warm climate: $\mathrm{STN}=0.0015 \times \mathrm{MAP} /(1+0.0021 \times$ MAP)), showing a higher saturation threshold in cold climates $\left(0.80 \mathrm{~kg} \mathrm{~N} \mathrm{~m}^{-2}\right)$ than warm climates $\left(0.65 \mathrm{~kg} \mathrm{~N} \mathrm{~m}^{-2}\right)$ (Fig. 6d). Combining the trends of SOC density and STN density, the $\mathrm{C}: \mathrm{N}$ ratio of the upper $30 \mathrm{~cm}$ layer increased with MAT in a climate of MAT $<0{ }^{\circ} \mathrm{C}$ and then decreased (Fig. 6e). In contrast, the $\mathrm{C}: \mathrm{N}$ ratio increased with MAP in accordance with a saturation curve (cold climate: $\mathrm{C}: \mathrm{N}=$ $0.1450 \times \mathrm{MAP} /(1+0.0080 \times \mathrm{MAP})$; warm climate: $\mathrm{C}: \mathrm{N}=$ $0.3781 \times \mathrm{MAP} /(1+0.0308 \times \mathrm{MAP}))$, showing a higher sat- 

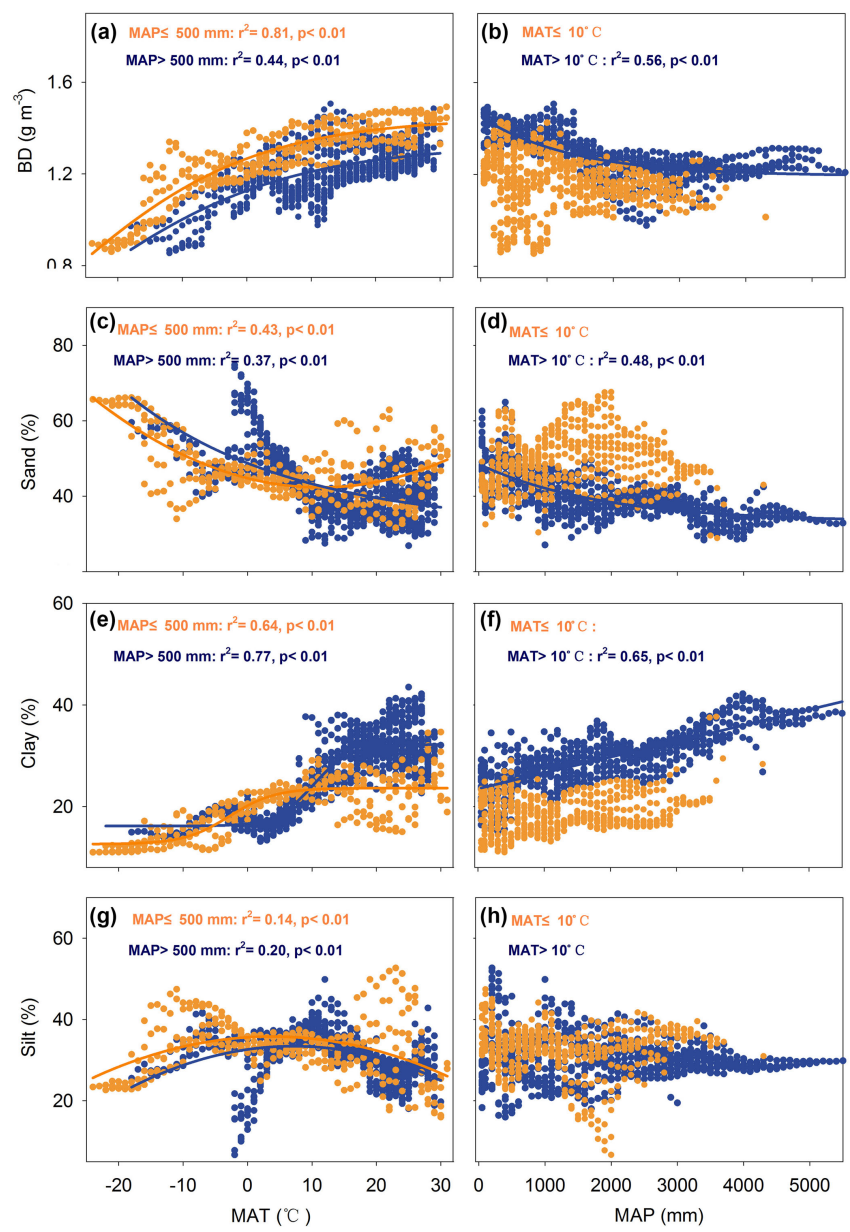

Figure 4. Changes in surface $(0-30 \mathrm{~cm})$ soil bulk density (BD, $\mathrm{g} \mathrm{m}^{-3}$ ), sand fraction (\%), clay fraction $(\%)$ and silt fraction $(\%)$ with mean annual precipitation (MAP) and mean annual temperature (MAT). We used $500 \mathrm{~mm}$ of MAP as a threshold of transition from arid to humid climate and $10^{\circ} \mathrm{C}$ of MAT as a threshold of transition from cool to warm climate. (a, b) BD, (c, d) sand fraction, (e, f) clay fraction, and $(\mathbf{g}, \mathbf{h})$ silt fraction. Each dot shows the average value within each $1^{\circ} \mathrm{C}$ MAT and $100 \mathrm{~mm}$ MAP.

uration threshold in cold climates $(18: 1)$ compared with warm climates (12:1) (Fig. 6f).

Soil properties showed varied values across and within biomes throughout the world (Table 1; Fig. 3). Mean bulk density was lowest in tundra and boreal forest and was highest in the desert and tropical thorn scrub and woodland (Table 1). Mean sand fraction was highest in boreal forest, whereas mean clay fraction was highest in tropical rainforest (Table 1). Soil pH was generally lower than 5.5 in tropical forest, boreal forest and tundra, but mean $\mathrm{pH}$ values could approach and even exceed 7.0 in dry biomes, such as the desert, grassland and savanna (Table 1). Moreover, means of SOC and STN densities both showed high values in boreal forest and tundra, but they were extremely low in the desert and tropical thorn scrub and woodland
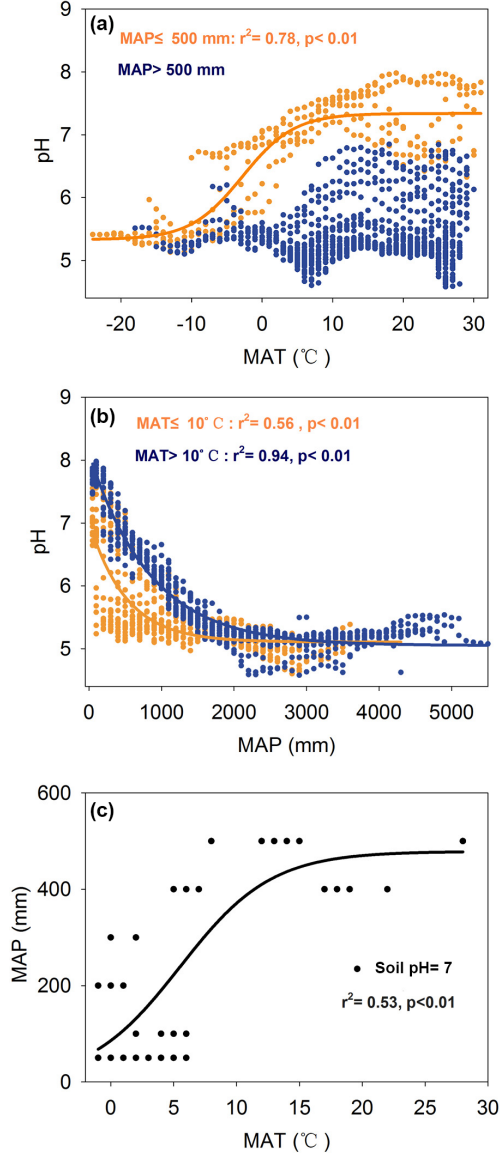

Figure 5. Changes in surface $(0-30 \mathrm{~cm})$ soil $\mathrm{pH}$ with climate. (a) Mean annual temperature (MAT); (b) mean annual precipitation (MAP), and (c) changes in "critical MAP" at soil $\mathrm{pH}=7.0$ with MAT. Here critical MAP means the corresponding MAP at a soil $\mathrm{pH}$ of $=7.0$, which indicates a shift from alkaline to acidic soil. We used MAP of $500 \mathrm{~mm}$ as a threshold of transition from arid to humid climate and MAT of $10^{\circ} \mathrm{C}$ as a threshold of transition from cool to warm climate.

(Table 1). Mean soil $\mathrm{C}: \mathrm{N}$ ratio showed the highest values in tundra and boreal forest $(>15: 1)$, while it was lowest in desert, temperate shrubs and grasslands $(\leq 10: 1)(\mathrm{Ta}-$ ble 1; Fig. 3h). On average, the global means of SOC density and STN density were $6.94(\mathrm{SD}=4.42) \mathrm{kg} \mathrm{C} \mathrm{m}^{-2}$ and $0.53(\mathrm{SD}=0.23) \mathrm{kg} \mathrm{N} \mathrm{m}^{-2}$ in surface soils, summing up to a global total storage of $797 \pm 4.1 \mathrm{Pg} \mathrm{C}\left(10^{15} \mathrm{~g}\right.$ or billion metric tons) and $64 \pm 0.4 \mathrm{Pg} \mathrm{N}$, respectively (Table 1).

\section{Discussion}

\subsection{Linkages between climate and surface soil physical properties}

The soil-climate-biome diagram demonstrated the quantitative linkages between surface soil physical properties and 


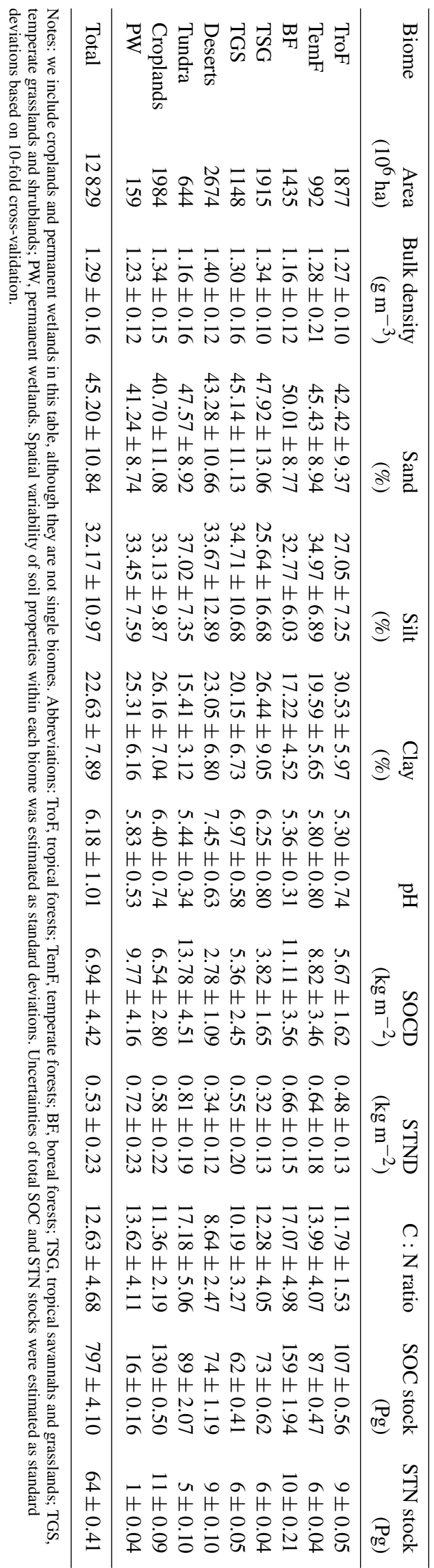

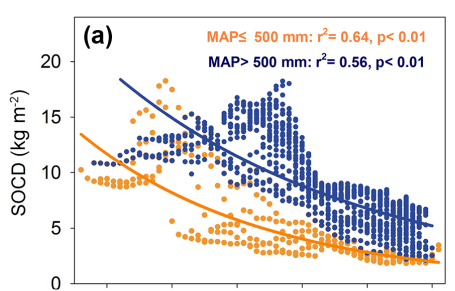
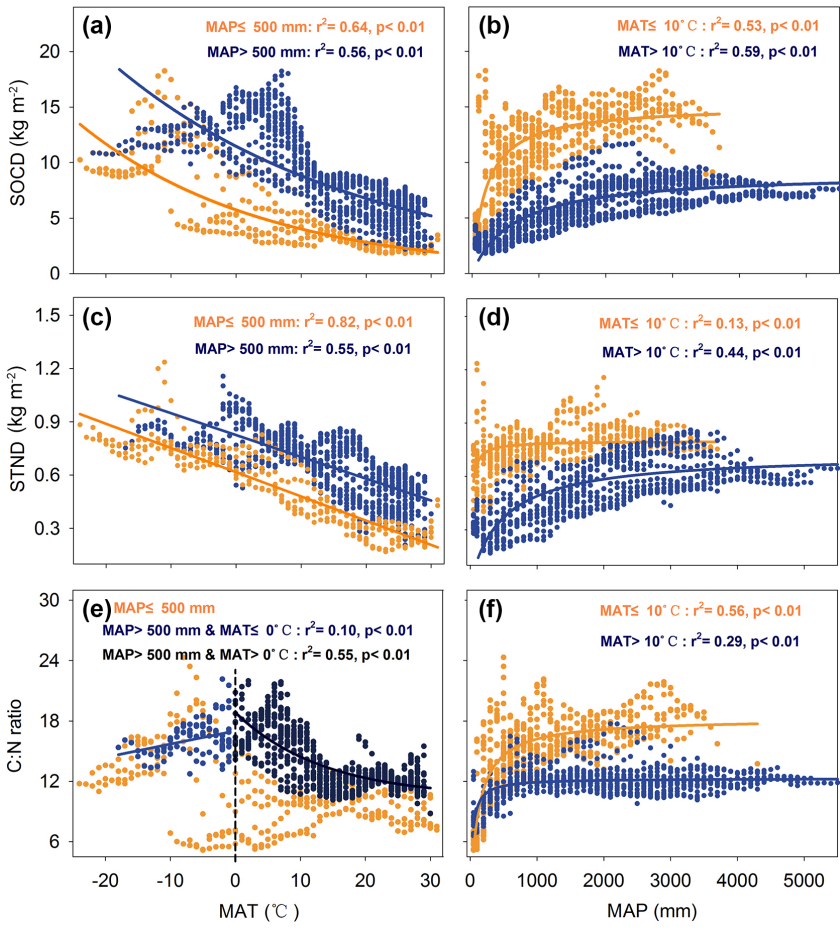

Figure 6. Changes in surface $(0-30 \mathrm{~cm})$ soil organic carbon density (SOCD), soil total nitrogen density (STND) and $\mathrm{C}: \mathrm{N}$ ratios with mean annual precipitation (MAP) and mean annual temperature (MAT). We used MAP of $500 \mathrm{~mm}$ as a threshold of transition from arid to humid climate and MAT of $10^{\circ} \mathrm{C}$ as a threshold of transition from cool to warm climate. (a, b) SOCD, (c, d) STND and (e, f) $\mathrm{C}: \mathrm{N}$ ratios. Each dot shows the average value within each $1{ }^{\circ} \mathrm{C}$ MAT and $100 \mathrm{~mm}$ MAP.

climate variables at the global scale. Compared with variables associated with topography (e.g., elevation and slope), vegetation activity (i.e., NDVI) and land cover (i.e., land use type), climate variables (such as MAT, MAP, TS and PS) were stronger predictors of bulk density and soil texture (Fig. 7a-c). This was likely due to the essential role of temperature and precipitation in physical, chemical and biological processes during soil formation (Weil and Brady, 2016). Specifically, bulk density showed an increase with higher MAT and lower MAP, likely due to an accompanying decrease in SOCD (Ruehlmann and Körschens, 2009), which was driven by stronger microbial decomposition under warmer and wetter conditions (Fig. 6; see more discussion on the effect of climate on SOCD in Sect. 4.3; Wiesmeier et al., 2019). In addition, higher MAT and MAP can accelerate the rate of weathering (Jenny, 1941; Lal and Stewart, 2018), thus resulting in lower sand fraction and higher soil clay fraction (Fig. 4). Along with topographical variables, climate may also affect soil physical properties via erosion processes. For example, soil erosion is highly selective to silt, while sand is less mobile due to high weight and clay is protected by soil 

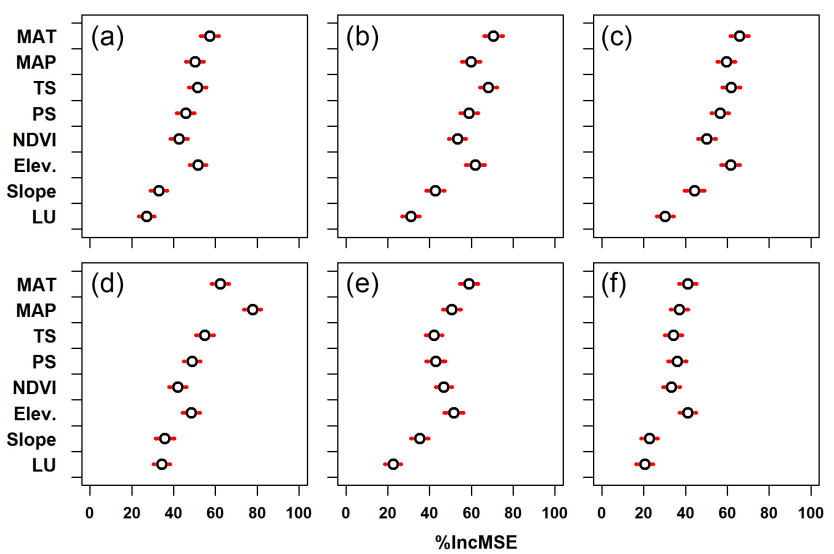

Figure 7. Importance of variables, denoted by the percent increase in mean-square error (\%IncMSE) for each soil property estimation: (a) BD (bulk density, $\mathrm{g} \mathrm{m}^{-3}$ ), (b) sand fraction (\%), (c) clay fraction $(\%),(\mathbf{d}) \mathrm{pH},(\mathbf{e}) \mathrm{SOCD}$ (soil organic carbon density, $\mathrm{kg} \mathrm{m}^{-2}$ ) and (f) STND (soil total nitrogen density, $\mathrm{kg} \mathrm{m}^{-2}$ ). MAT, MAP, TS, PS, Elev. and LU indicate mean annual temperature, mean annual precipitation, annual temperature seasonality, annual precipitation seasonality, elevation and land use type, respectively.

aggregates (Wischmeier and Mannering, 1969; Torri et al., 1997; Wang et al., 2013).

Other factors, such as historical tectonics, glaciations and soil ages, could also affect soil physical properties (Jenny, 1941; Weil and Brady, 2016), but they are often spatially correlated with climate variables, making it difficult to separate their role from the latter. For instance, the effect of glaciations is stronger, the soil age is younger and air temperature is lower towards higher latitudes. Likewise, the role of tectonics in rejuvenating younger soils might also be mixed by corresponding climatic conditions across altitudinal gradients. In tropical regions, we found a significant decrease in bulk density and clay fraction with higher elevation (Fig. S6a, d). This decrease in bulk density along the altitude gradient was likely due to an increase in SOC retention (Fig. S6f), resulting from low rates of soil organic matter decomposition along with lower temperature (Grieve et al., 1990; Kramer and Chadwick, 2016). Meanwhile, the decrease in clay fraction with higher altitude was likely due to a younger soil age (Waite and Sack, 2011), lower weathering rate under lower temperature (Grieve et al., 1990; Kramer and Chadwick, 2016) and a downslope translocation of surface soil to lower altitudes. Interestingly, these altitudinal gradients were consistent with the results of field studies (Dieleman et al., 2013) and also mirrored a similar trend across latitudes.

\subsection{The key role of climate in determining global patterns of surface soil chemical properties}

Our results indicated that MAP was the most important surrogate for soil $\mathrm{pH}$ prediction (Fig. 7d). Such a pattern might be due to the increased leaching of exchangeable base cations across large-scale precipitation gradients (Jenny, 1941). Interestingly, further analysis showed that the critical levels of MAP for the transition from alkaline to acidic soil decreased nonlinearly with lower MAT, owing to changing water balance (Fig. 5). Specifically, the critical MAP ranged from 400 to $500 \mathrm{~mm}$ when the MAT exceeded $10^{\circ} \mathrm{C}$ and could decrease to $50-100 \mathrm{~mm}$ when MAT was close to $0^{\circ} \mathrm{C}$, highlighting significant interactions between MAP and MAT. Such a pattern was supported by a recent study, which revealed that the transition from alkaline to acidic soil occurred when the MAP began to exceed the mean annual potential evapotranspiration (Slessarev et al., 2016). It should be noted that, other factors besides climate variables, such as acid deposition, may also contribute to regional-scale patterns of soil pH, especially in Europe, eastern North America and southern China, which have received high-level acid deposition (Bouwman et al., 2002; Vet et al., 2014).

Our analysis also indicated that climate variables (e.g., MAT, MAP) were the strongest predictors of SOC density (Fig. 7e), in agreement with the findings of previous studies (Post et al., 1982; Gray et al., 2009). Such a pattern reflects the fact that soil $\mathrm{C}$ stock depends on the balance between plant inputs (i.e., litterfall and other plant debris) and microbially mediated metabolic losses of $\mathrm{CO}_{2}$ to atmosphere (Stockmann et al., 2013), which are strongly controlled by climate (Davidson and Janssens, 2006; Bond-Lamberty and Thomson, 2010). In general, precipitation favors net primary productivity (Del Grosso et al., 2008) and the consequent C inputs into the soil, while it intensifies weathering of the parent material and soil acidification, thus increasing formation of SOC-stabilizing minerals (Chaplot et al., 2010; Doetterl et al., 2015) and reducing decomposition of soil organic matter (Meier and Leuschner, 2010). These processes could then explain the increase in SOCD with MAP (Fig. 6), while it did not exceed a certain threshold because of a constraint of C inputs (Del Grosso et al., 2008). Compared with precipitation, temperature largely affects the rate and degree of microbial decomposition of soil organic matter (Wiesmeier et al., 2019). Consequently, SOCD increased with lower MAT (Fig. 6), while it reached saturation due to a threshold of SOC stabilization (Doetterl et al., 2015).

Further analysis also revealed an interaction between MAT and MAP in shaping the patterns of SOC density. For instance, SOC density showed a tendency of saturation with higher MAP, while the saturation thresholds were higher under MAT $\leq 10^{\circ} \mathrm{C}$ compared to MAT $>10^{\circ} \mathrm{C}$ (Fig. 6). Specifically, the saturation threshold for SOC density under MAT $\leq 10^{\circ} \mathrm{C}\left(14.5 \mathrm{~kg} \mathrm{C} \mathrm{m}^{-2}\right)$ were nearly twice of that under MAT $>10^{\circ} \mathrm{C}\left(8.0 \mathrm{~kg} \mathrm{C} \mathrm{m}^{-2}\right)$ (Fig. 6b). These critical levels of SOCD imply a saturation threshold of SOC stocks under certain climate regime (Stewart et al., 2007). Soil C saturation has also been evidenced by experimental studies, which indicate that SOC pool has an upper limit with respect to $\mathrm{C}$ input levels because of a threshold of SOM stabilization efficiency (Stewart et al., 2008; Kimetu et al., 2009). These 


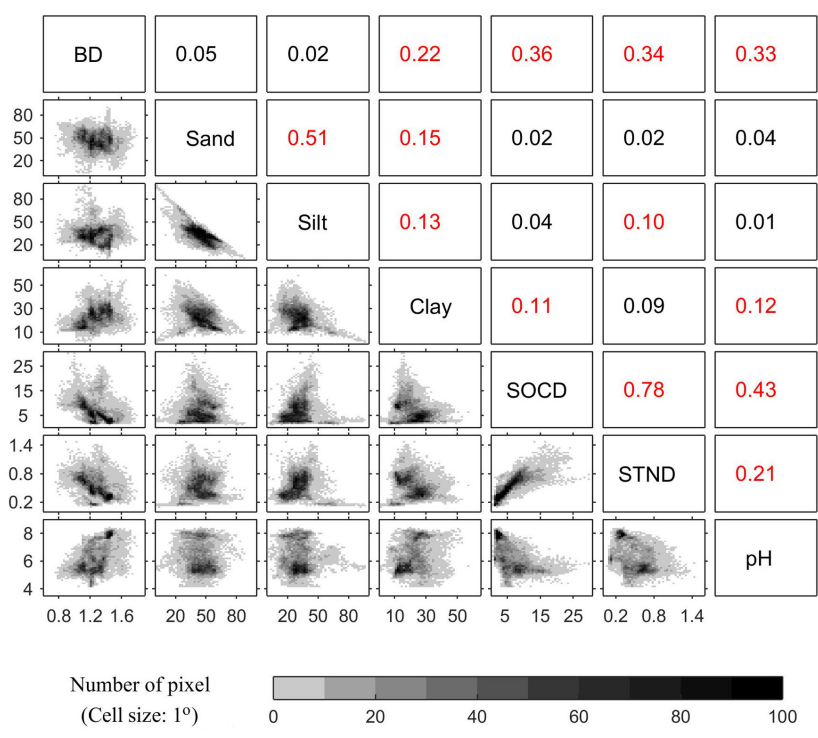

Figure 8. Correlation between surface $(0-30 \mathrm{~cm})$ soil properties. $R^{2}$ between each two soil properties is shown in the upper plots with red color indicating $R^{2}>0.1$. BD, SOCD and STND indicate bulk density, soil organic carbon density and soil total nitrogen density, respectively.

thresholds of soil C saturation can help to estimate soil C sequestration potential and provide important guidelines for regional soil steward and ecosystem management.

Previous meta-analyses indicated that $\mathrm{C}: \mathrm{N}$ ratio in the soil was well-constrained at the global scale (Cleveland and Liptzin, 2007). Accordingly, our results indicated a strong correlation between STN density and SOC density (Fig. 8) and demonstrated a similar pattern of STN density as SOC density across biome and climate regimes (Figs. 3 and 6). Based on a synthesis of long-term experimental results, Manzoni et al. (2008) demonstrated that the $\mathrm{C}: \mathrm{N}$ ratio of the litter decreased throughout decomposition. Because soil organic matter is a result of long-term decomposition, surface soil $\mathrm{C}: \mathrm{N}$ ratio is thus negatively correlated with decomposition degree while positively correlated with SOC content and turnover time (Carvalhais et al., 2014). Our analysis also indicated that higher soil $\mathrm{C}: \mathrm{N}$ ratios were associated with higher SOC density (Figs. 2, 3).

\subsection{Shifts in soil properties across biomes and land use types}

Our analysis indicated that soil properties varied significantly across global biomes (Table 1). For example, SOC density showed high values in boreal forests and tundra due to the slower microbial decomposition compared with biomass inputs (Hobbie et al., 2000; Hashimoto et al., 2015; Bloom et al., 2016), but these values were extremely low in drylands due to low plant cover and productivity (Delgado-Baquerizo et al., 2013). Due to fast turnover with rapid decomposition of organic matter, SOC content is relatively poor in tropical forests (e.g., the Congo and Amazon tropical forests in Fig. 2f) (Carvalhais et al., 2014; Wang et al., 2018). Accordingly, previous mappings of SOC density have also shown relatively low values in tropical forests (Köchy et al., 2015; Jackson et al., 2017). In view of a strong and negative correlation between SOC and bulk density, bulk density showed an opposite shift across biomes (Table 1). Moreover, we also found an increase in SOC density and a decrease in soil bulk density with elevation (Fig. S6a and f), likely due to a shift in climate regime and vegetation type.

The effect of land use is important for the SOC stock at a regional to local scale. A change of forest or grassland to croplands can significantly decrease SOC density and thus decrease soil bulk density, while reforestation generally increases SOC density and decreases soil bulk density (DeGryze et al., 2004; Machmuller et al., 2015). When comparing values in the same region (e.g., Southeast Asia), SOC density is obviously lower in croplands than in forests (Fig. S7a and b). This difference has been also evidenced by meta-analysis based on field observations (Don et al., 2011). In the Mediterranean region, an increase in the area of olive plantations and vineyard in last few decades have likely contributed to a consequent increase in SOC density (ParrasAlcántara et al., 2013). Moreover, a recent assessment indicates that ecological restoration projects (e.g., Three-North Shelter Forest Program, Natural Forest Protection Project, Grain for Green Program, Returning Grazing Land to Grassland Project) in China have substantially increased soil and biomass $\mathrm{C}$ storage in the corresponding regions ( $\mathrm{Lu}$ et al., 2018). However, our static mapping of global soil properties is not able to account for the effect of temporal land use change on SOC density.

\subsection{Global carbon and nitrogen stocks in surface soils}

Earlier estimates of global SOC and STN stocks were based on either an area-weighted extrapolation or an empirical model of the soil profile data according to climate, vegetation type or soil order (Post et al., 1982; Batjes, 1996, 2009; Hengl et al., 2014; Scharlemann et al., 2014). In the range of these estimates, our results based on RF modeling indicated that the global stocks of SOC were $788 \pm 39.4 \mathrm{Pg}$ in the upper $30 \mathrm{~cm}$ soil layer. Reports of global STN stocks are relatively rare compared with those of SOC stocks. Based on information on measured soil profiles, Batjes (1996) estimated global STN stocks to be 63-67 Pg N in the upper $30 \mathrm{~cm}$ layers. Similar to the estimates by Batjes (1996), our results indicate that global STN stocks were $63 \pm 3.3 \mathrm{Pg}$ in the upper $30 \mathrm{~cm}$ soil layer (Table 1). Despite similar estimation of global total SOC and STN stocks, our regional RF analysis has several advantages, such as the ability to model nonlinear relationships, handle both categorical and continuous predictors, and resist overfitting and noise features (Breiman, 2001). By using climate, vegetation, topography and land use variables as 
predictors, our region-specific RF approach likely produces more robust global maps of soil properties at a finer spatial resolution.

\subsection{Uncertainties in mapping surface soil properties at the global scale}

In this study, we used machine learning algorithms to map global surface soil properties at a $1 \mathrm{~km}$ resolution. Although this approach could overcome uncertainties derived from large variations in mapping units, several limitations still exist in our analysis. First, the limited sample size in certain areas may lead to estimation uncertainties. Particularly, the accuracy of the region-specific RF model partially depends on the number of sampling sites and the evenness of the spatial pattern. The limited number and uneven distribution of the soil profile may thus constrain the accuracy of regionspecified RF models, especially in regions such as Russia and South America (Table S5).

Second, soil properties have been measured using various approaches and compiled for several decades, while there are no straightforward solutions to accurately harmonize the data at the global level (Maire et al., 2015; Batjes, 2016). The errors due to varied sampling and measurement methods over time may lead to uncertainties in our analysis. Moreover, our database includes pedologic information on soil orders and soil horizons of sampled soil profiles and these data were originally reported based on several different soil classification systems using different standards (Batjes et al., 2007; Carter and Bentley, 2016). It is thus a challenge for us to harmonize the data on soil orders and soil horizons and quantify their impacts on surface soil properties. Nevertheless, the depth of $0-30 \mathrm{~cm}$ has been frequently used in the mapping and modeling of surface soil properties at regional and global scales (e.g., Batjes, 1997; Yang et al., 2010; Saiz et al., 2012; Wieder et al., 2013; Shangguan et al., 2014). By considering essential climatic variables (MAT, MAP, seasonality of air temperature, seasonality of precipitation), vegetation parameters (mean annual NDVI and land use type) and topographic factors (elevation, slope) that are key to soil formation (Jenny, 1941), our random forest analysis may have partially constrained the uncertainties due to the lack of information on soil orders and associated soil horizons.

Finally, uncertainties may also arise from the limited independent variables used in this study. Although essential surrogate variables of climate, topography, vegetation activity and land cover were incorporated in our analysis, we still could not account for the role of soil horizons, soil ages and parental material characteristics due to the lack of globalscale dataset. For instance, surface soil (top $30 \mathrm{~cm}$ ) can contain either a single horizon or several very different horizons with very different physical and chemical properties. Soil mineralogy, being a function of parent material, climate and soil age (Jenny, 1941), has been demonstrated to be important in determining the quantity of SOC storage and its turnover time during long-term soil development (Torn et al., 1997). Soil age may also play an important role in forming soil properties (Jenny, 1941), but it is hard to evaluate its individual role in regulating spatial patterns of soil properties due to its strong interactions with climate variables. Therefore, future studies should make more efforts to consider these variables when predicting spatial patterns of soil physical and chemical properties at the global scale.

\section{Conclusion}

By compiling a comprehensive global soil database, we mapped eight surface soil properties based on machine learning algorithms and assessed the quantitative linkages between soil properties, climate and biota at the global scale. Our region-specific random forest model generated high-resolution $(1 \mathrm{~km})$ predictions of surface soil properties, which can be potentially used as inputs for regional and global biogeochemical models. Our results also produced a global soil-climate-biome diagram, which indicates the quantitative linkages between soil, climate and biomes. Given that significant changes in major soil properties may occur in view of global environmental change (Trumbore and Czimczik, 2008; Chapin III et al., 2009; Todd-Brown et al., 2013; Luo et al., 2016, 2017), more efforts should be made in future to understand the dynamics of the global soil-climatebiome diagram.

Data availability. All data included in this study are available upon request by contact with the corresponding author.

Supplement. The supplement related to this article is available online at: https://doi.org/10.5194/bg-16-2857-2019-supplement.

Author contributions. JF designed the research. JF, XZ and YY collected and analyzed the data and the manuscript was written by XZ, YY and JF and commented on by all the other authors.

Competing interests. The authors declare that they have no conflict of interest.

Acknowledgements. We thank Huifeng Hu, Zhaodi Guo, Chao Yue, Jinyu Sun, Bing Xu and Shengli Tao for their assistance in data collection and preparation of the manuscript.

Financial support. This research has been supported by the National Key Research and Development Program (grant no. 2017YFC0503901), the National Natural Science Foundation of China (grant nos. 31700419, 31321061 and 31330012) and the Key 
Research Program of Frontier Sciences, CAS (grant no. QYZDYSSW-SMC011).

Review statement. This paper was edited by Yakov Kuzyakov and reviewed by Petr Capek and three anonymous referees.

\section{References}

Abdelbaki, A.: Evaluation of pedotransfer functions for predicting soil bulk density for US soils, Ain. Shams. Eng. J., 9, 1611-1619, 2018.

Adhikari, K. and Hartemink, A. E.: Linking soils to ecosystem services - A global review, Geoderma, 262, 101-111, 2016.

Alexander, E. B.: Soils in natural landscapes, CRC Press/Taylor \& Francis Group, Boca Ration, FL, USA, 2013.

Amundson, R., Berhe, A. A., Hopmans, J. W., Olson, C., Sztein, A. E., and Sparks, D. L.: Soil and human security in the 21st century, Science, 348, 1261071, https://doi.org/10.1126/science.1261071, 2015.

Arrouays, D., McKenzie, N., Hempel, J., de Forges, A. R., and McBratney, A. B. (Eds.): GlobalSoilMap: basis of the global spatial soil information system, CRC Press/Taylor \& Francis Group, Boca Ration, FL, USA, 2014.

Batjes, N. H.: Total carbon and nitrogen in the soils of the world, Eur. J. Soil Sci., 47, 151-163, 1996.

Batjes, N. H.: A world dataset of derived soil properties by FAOUNESCO soil unit for global modelling, Soil Use Manage., 13, 9-16, 1997.

Batjes, N. H.: Harmonized soil profile data for applications at global and continental scales: updates to the WISE database. Soil Use Manage., 25, 124-127, 2009.

Batjes, N. H.: Harmonized soil property values for broad-scale modelling (WISE30sec) with estimates of global soil carbon stocks. Geoderma, 269, 61-68, 2016.

Batjes, N. H., Al-Adamat, R., Bhattacharyya, T., Bernoux, M., Cerri, C. E. P., Gicheru, P., Kamoni, P., Milne, E., Pal, D. K., and Rawajfih, Z.: Preparation of consistent soil data sets for modelling purposes: Secondary SOTER data for four case study areas, Agr. Ecosyst. Environ., 122, 26-34, 2007.

Bloom, A. A., Exbrayat, J. F., van der Velde, I. R., Feng, L., and Williams, M.: The decadal state of the terrestrial carbon cycle: Global retrievals of terrestrial carbon allocation, pools, and residence times, P. Natl. Acad. Sci. USA, 113, 1285-1290, 2016.

Bond-Lamberty, B. and Thomson, A.: Temperature-associated increases in the global soil respiration record, Nature, 464, 579582,2010

Bouwman, A. F., Van Vuuren, D. P., Derwent, R. G., and Posch, M.: A global analysis of acidification and eutrophication of terrestrial ecosystems, Water Air Soil Poll., 141, 349-382, 2002.

Breiman, L.: Random forests, Mach. Learn., 45, 5-32, 2001.

Carter, M. and Bentley, S. P.: Soil properties and their correlations, John Wiley \& Sons, New York, NY, USA, 2016.

Carvalhais, N., Forkel, M., Khomik, M., Bellarby, J., Jung, M., Migliavacca, M., Mu, M., Saatchi, S., Santoro, M., Thurner, M., Weber, U., Ahrens B., Beer, C., Cescatti, A., Randerson, J. T., and Reichstein, M.: Global covariation of carbon turnover times with climate in terrestrial ecosystems, Nature, 514, 213-217, 2014.

Castellano, M. J. and Kaye, J. P.: Global within-site variance in soil solution nitrogen and hydraulic conductivity are correlated with clay content, Ecosystems, 12, 1343-1351, 2009.

Chapin III, S., McFarland, J., McGuire, D. A., Euskirchen, E. S., Ruess, R. W., and Kielland, K.: The changing global carbon cycle: linking plant-soil carbon dynamics to global consequences, J. Plant. Ecol., 97, 840-850, 2009.

Chaplot, V., Bouahom, B., and Valentin, C.: Soil organic carbon stocks in Laos: spatial variations and controlling factors, Glob. Change Biol., 16, 1380-1393, 2010.

Chesworth, W.: The parent rock effect in the genesis of soil, Geoderma, 10, 215-225, 1973.

Cleveland, C. C. and Liptzin, D.: C : N : P stoichiometry in soil: is there a "Redfield ratio" for the microbial biomass?, Biogeochemistry, 85, 235-252, 2007.

Davidson, E. A. and Janssens, I. A.: Temperature sensitivity of soil carbon decomposition and feedbacks to climate change, Nature, 440, 165-173, 2006.

DeGryze, S., Six, J., Paustian, K., Morris, S. J., Paul, E. A., and Merckx, R.: Soil organic carbon pool changes following landuse conversions, Glob. Change Biol., 10, 1120-1132, 2004.

Del Grosso, S., Parton, W., Stohlgren, T., Zheng, D., Bachelet, D., Prince, S., Hibbard, K., and Olson, R.: Global potential net primary production predicted from vegetation class, precipitation, and temperature, Ecology, 89, 2117-2126, 2008.

Delgado-Baquerizo, M., Maestre, F. T., Gallardo, A., Bowker, M. A., Wallenstein, M. D., Quero, J. L., and García-Palacios, P.: Decoupling of soil nutrient cycles as a function of aridity in global drylands, Nature, 502, 672-676, 2013.

Dieleman, W. I., Venter, M., Ramachandra, A., Krockenberger, A. K., and Bird, M. I.: Soil carbon stocks vary predictably with altitude in tropical forests: implications for soil carbon storage, Geoderma, 204, 59-67, 2013.

Ding, J., Li, F., Yang, G., Chen, L., Zhang, B., Liu, L., and Ji, C.: The permafrost carbon inventory on the Tibetan Plateau: a new evaluation using deep sediment cores, Glob. Change Biol., 22, 2688-2701, 2016.

Doetterl, S., Stevens, A., Six, J., Merckx, R., Van Oost, K., Pinto, M. C., Casanova-Katny, A., Muñoz, C., Boudin, M., Venegas, E. Z., and Boeckx, P.: Soil carbon storage controlled by interactions between geochemistry and climate, Nat. Geosci., 8, 780-783, 2015.

Don, A., Schumacher, J., and Freibauer, A.: Impact of tropical landuse change on soil organic carbon stocks-a meta-analysis, Glob. Change Biol., 17, 1658-1670, 2011.

Gentsch, N., Wild, B., Mikutta, R., Capek, P., Diáková, K., Schrumpf, M., Turner, S., Minnich, C., Schaarschmidt, F., Shibistova, O., Schnecker, J., Urich, T., Gittel, A., Šantrůčková, H., Bárta, J., Lashchinskiy, N., Fu, R., Richter, A., and Guggenberger, G.: Temperature response of permafrost soil carbon is attenuated by mineral protection, Glob. Change Biol., 24, 34013415, 2018.

Gray, J. M., Humphreys, G. S., and Deckers, J. A.: Relationships in soil distribution as revealed by a global soil database, Geoderma, 150, 309-323, 2009.

Grieve, I. C., Proctor, J., and Cousins, S. A.: Soil variation with altitude on volcan Barva, Costa Rica, Catena, 17, 525-534, 1990. 
Grimm, R., Behrens, T., Märker, M., and Elsenbeer, H.: Soil organic carbon concentrations and stocks on Barro Colorado Island Digital soil mapping using Random Forests analysis, Geoderma, 146, 102-113, 2008.

Grunwald, S., Thompson, J. A., and Boettinger, J. L.: Digital soil mapping and modeling at continental scales: Finding solutions for global issues, Soil Sci. Soc. Am. J., 75, 1201-1213, 2011.

Hashimoto, S., Carvalhais, N., Ito, A., Migliavacca, M., Nishina, K., and Reichstein, M.: Global spatiotemporal distribution of soil respiration modeled using a global database, Biogeosciences, 12, 4121-4132, https://doi.org/10.5194/bg-12-4121-2015, 2015.

Hassink, J.: The capacity of soils to preserve organic $\mathrm{C}$ and $\mathrm{N}$ by their association with clay and silt particles, Plant Soil, 191, 7787, 1997.

Hengl, T., de Jesus, J. M., MacMillan, R. A., Batjes, N. H., Heuvelink, G. B., Ribeiro, E., Samuel-Rosa, A., Kempen, B., Leenaars, J. G. B., Walsh, M., and Gonzalez, M. R.: SoilGrids1km - global soil information based on automated mapping, PLoS One, 9, e105992, https://doi.org/10.1371/journal.pone.0105992, 2014.

Hengl, T., de Jesus, J. M., Heuvelink, G. B., Gonzalez, M. R., Kilibarda, M., Blagotić, A., and Guevara, M. A.: SoilGrids250m: Global gridded soil information based on machine learning, PloS One, 12, e0169748, https://doi.org/10.1371/journal.pone.0169748, 2017.

Hobbie, S. E., Schimel, J. P., Trumbore, S. E., and Randerson, J. R.: Controls over carbon storage and turnover in high-latitude soils, Glob. Change Biol., 6, 196-210, 2000.

Holdridge, L. R.: Life zone ecology, Tropical Science Center, San Jose, Costa Rica, 1967.

Jackson, R. B., Lajtha, K., Crow, S. E., Hugelius, G., Kramer, M. G., and Piñeiro, G.: The ecology of soil carbon: pools, vulnerabilities, and biotic and abiotic controls, Annu. Rev. Ecol. Evol. S., 48, 419-445, 2017.

Jandl, R., Rodeghiero, M., Martinez, C., Cotrufo, M. F., Bampa, F., van Wesemael, B., and Lorenz, K.: Current status, uncertainty and future needs in soil organic carbon monitoring, Sci. Total Environ., 468, 376-383, 2014.

Jenny, H.: Factors of soil formation: a system of quantitative pedology, McGraw-Hill Book Company Inc, New York, 1941.

Jilling, A., Keiluweit, M., Contosta, A. R., Frey, S., Schimel, J., Schnecker, J., Smith, R. G., Tiemann, L., and Grandy, A. S.: Minerals in the rhizosphere: overlooked mediators of soil nitrogen availability to plants and microbes, Biogeochemistry, 139, 103-122, 2018.

Jiménez-Muñoz, J. C., Mattar, C., Sobrino, J. A., and Malhi, Y.: A Database for the Monitoring of Thermal Anomalies Over the Amazon Forest and Adjacent Intertropical Oceans, Scientific Data, 2, 150024, https://doi.org/10.1038/sdata.2015.24, 2015.

Kimetu, J. M., Lehmann, J., Kinyangi, J. M., Cheng, C. H., Thies, J., Mugendi, D. N., and Pell, A.: Soil organic C stabilization and thresholds in C saturation, Soil Biol. Biochem., 41, 2100-2104, 2009.

Koch, A., McBratney, A., Adams, M., Field, D., Hill, R., Crawford, J., and Angers, D.: Soil security: solving the global soil crisis, Glob. Policy, 4, 434-441, 2013.

Köchy, M., Hiederer, R., and Freibauer, A.: Global distribution of soil organic carbon - Part 1: Masses and frequency distributions of SOC stocks for the tropics, permafrost regions, wetlands, and the world, SOIL, 1, 351-365, https://doi.org/10.5194/soil-1-3512015, 2015.

Kramer, M. G. and Chadwick, O. A.: Controls on carbon storage and weathering in volcanic soils across a high-elevation climate gradient on Mauna Kea, Hawaii, Ecology, 97, 2384-2395, 2016.

Lal, R. and Stewart B. A. (Eds.): Soil and climate, in: Soil and Climate, 1-8, CRC Press/Taylor \& Francis Group, Boca Ration, FL, USA, 2018.

Lu, F., Hu, H., Sun, W., Zhu, J., Liu, G., Zhou, W., Zhang, Q., Shi, P., Liu, X., Wu, X., Zhang, L., Wei, X., Dai, L., Zhang, K., Sun Y., Xue, S., Zhang, W., Xiong, D., Deng, L., Liu, B., Zhou, L., Zhang, C., Zheng, X., Cao, J., Huang, Y., He, N., Zhou, G., Bai, Y., Xie, Z., Tang, Z., Wu, B., Fang, J., Liu, G., and Yu, G.: Effects of national ecological restoration projects on carbon sequestration in China from 2001 to 2010, P. Natl. Acad. Sci. USA, 115, 4039-4044, 2018.

Luo, Y., Ahlström, A., Allison, S. D., Batjes, N. H., Brovkin, V., Carvalhais, N., Chappell, A., Ciais, P., Davidson, E., Finzi, A., Georgiou, K., Guenet, B., Hararuk, O., Hararuk, O., Harden, J. W., He Y. J., Hopkins, F., Jiang, L. F., Koven, C., Jackson, R. B., Jones, C. D., Lara, M. J., Liang J. Y., McGuire A. D., Parton, W., Peng, C. H., Randerson, J. T., Salazar, A., Sierra, C. A., Smith, M. J., Tian, H. Q., Todd-Brown, K. E. O., Torn, M., van Groenigen, K. J., Wang, Y. P., West, T. O., Wei Y. X., Wieder, W. R., Xia, J. Y., Xu, X., Xu, X. F., and Zhou, T.: Toward more realistic projections of soil carbon dynamics by Earth system models, Global Biogeochem. Cy., 30, 40-56, 2016.

Luo, Z., Wang, E., and Sun, O.J.: Uncertain future soil carbon dynamics under global change predicted by models constrained by total carbon measurements, Ecol. Appl., 27, 1001-1009, 2017.

Machmuller, M. B., Kramer, M. G., Cyle, T. K., Hill, N., Hancock, D., and Thompson, A.: Emerging land use practices rapidly increase soil organic matter, Nat. Commun., 6, 6995, https://doi.org/10.1038/ncomms7995, 2015.

Maire, V., Wright, I. J., Prentice, I. C., Batjes, N. H., Bhaskar, R., Bodegom, P. M., and Reich, P. B.: Global effects of soil and climate on leaf photosynthetic traits and rates, Global Ecol. Biogeogr., 24, 706-717, 2015.

Manzoni, S., Jackson, R. B., Trofymow, J. A., and Porporato, A.: The global stoichiometry of litter nitrogen mineralization, Science, 321, 684-686, 2008.

Meier, I. C. and Leuschner, C.: Variation of soil and biomass carbon pools in beech forests across a precipitation gradient, Glob. Change Biol., 16, 1035-1045, 2010.

Milne, E., Banwart, S. A., Noellemeyer, E., Abson, D. J., Ballabio, C., Bampa, F., and Black, H.: Soil carbon, multiple benefits, Environ. Dev., 13, 33-38, 2015.

National Soil Survey Office: Chinese Soil Genus Records, Volume 1-6, Chinese Agriculture Press, 1995 (in Chinese).

National Soil Survey Office: Chinese Soils, Chinese Agriculture Press, 1998 (in Chinese).

Pan, Y., Birdsey, R. A., Fang, J., Houghton, R., Kauppi, P. E., Kurz, W. A., and Ciais, P.: A large and persistent carbon sink in the world's forests, Science, 333, 988-993, 2011.

Parras-Alcántara, L., Martín-Carrillo, M., and Lozano-García, B.: Impacts of land use change in soil carbon and nitrogen in a Mediterranean agricultural area (Southern Spain), Solid Earth, 4, 167-177, https://doi.org/10.5194/se-4-167-2013, 2013. 
Pleijsier, J.: Variability in soil data, in: Land Qualities in Space and Time, edited by: Bouma, J. and Bregt, A. K., 89-98, Pudoc, Wageningen, 1989.

Post, W. M., Emanuel, W. R., Zinke, P. J., and Stangenberger, A. G.: Soil carbon pools and world life zones, Nature, 298, 156159, 1982.

Rohli, R. V., Joyner, T. A., Reynolds, S. J., and Ballinger, T. J.: Overlap of global Köppen-Geiger climates, biomes, and soil orders, Phys. Geogr., 36, 158-175, 2015.

Ruehlmann, J. and Körschens, M.: Calculating the effect of soil organic matter concentration on soil bulk density, Soil Sci. Soc. Am. J., 73, 876-885, 2009.

Saiz, G., Bird, M. I., Domingues, T., Schrodt, F., Schwarz, M., Feldpausch, T. R., and Diallo, A.: Variation in soil carbon stocks and their determinants across a precipitation gradient in West Africa, Glob. Change Biol., 18, 1670-1683, 2012.

Saiz, G., Bird, M. I., Domingues, T., Schrodt, F., Schwarz, M., Feldpausch, T. R., Veenendaal, E., Djagbletey, G., Hien, F., Compaore, H., and Diallo, A.: Variation in soil carbon stocks and their determinants across a precipitation gradient in West Africa, Glob. Change Biol., 18, 1670-1683, 2012.

Sanchez, P. A., Ahamed, S., Carré, F., Hartemink, A. E., Hempel, J., Huising, J., and Minasny, B.: Digital soil map of the world, Science, 325, 680-681, 2009.

Schaap, M. G. and Leij, F. J.: Database-related accuracy and uncertainty of pedotransfer functions, Soil Sci., 163, 765-779, 1998.

Scharlemann, J. P. W., Tanner, E. V. J., Hiederer, R., and Kapos V.: Global soil carbon: understanding and managing the largest terrestrial carbon pool, Carbon Manag., 5, 81-91, 2014.

Shangguan, W., Dai, Y., Duan, Q., Liu, B., and Yuan, H.: A global soil data set for earth system modeling, J. Adv. Model Earth Sy., 6, 249-263, 2014.

Slessarev, E. W., Lin, Y., Bingham, N. L., Johnson, J. E., Dai, Y., Schimel, J. P., and Chadwick, O. A.: Water balance creates a threshold in soil $\mathrm{pH}$ at the global scale, Nature, 540, 567-569, 2016.

Sposito, G., Skipper, N. T., Sutton, R., Park, S. H., Soper, A. K., and Greathouse, J. A.: Surface geochemistry of the clay minerals, P. Natl. Acad. Sci. USA, 96, 3358-3364, 1999.

Stewart, C. E., Paustian, K., Conant, R. T., Plante, A. F., and Six, J.: Soil carbon saturation: concept, evidence and evaluation, Biogeochemistry, 86, 19-31, 2007.

Stewart, C. E., Paustian, K., Conant, R. T., Plante, A. F., and Six, J.: Soil carbon saturation: evaluation and corroboration by longterm incubations, Soil Biol. Biochem., 40, 1741-1750, 2008.

Stockmann, U., Adams, M. A., Crawford, J. W., Field, D. J., Henakaarchchi, N., Jenkins, M., and Wheeler, I.: The knowns, known unknowns and unknowns of sequestration of soil organic carbon, Agr., Ecosyst. Environ., 164, 80-99, 2013.

Strobl, C., Hothorn, T., and Zeileis, A.: Party on! A new, conditional variable importance measure for random forests available in party package, R J., 1, 14-17, 2009a.

Strobl, C., Malley, J., and Tutz, G.: An introduction to recursive partitioning: rationale, application, and characteristics of classification and regression trees, bagging, and random forests, Psychol. Methods, 14, 323-348, 2009b.

Tarnocai, C., Canadell, J. G., Schuur, E. A. G., Kuhry, P., Mazhitova, G., and Zimov, S.: Soil organic carbon pools in the north- ern circumpolar permafrost region, Global Biogeochem. Cy., 23, GB2023, https://doi.org/10.1029/2008GB003327, 2009.

Tian, H. Q., Lu, C. Q., Yang, J., Banger, K., Huntzinger, D. N., Schwalm, C. R., Michalak, A. M., Cook, R., Ciais, P., Hayes, D., Huang, M. Y., Ito, A., Jain, A. K., Lei, H. M., Mao, J. F., Pan S. F., Post, W.M., Peng, S. S., Poulter, Ren, W., Ricciuto D., Schaefer, K., Shi, X. Y., Tao, B., Wang, W. L., Wei, Y. X., Yang, Q. C., Zhang, B., and Zeng, N.: Global patterns and controls of soil organic carbon dynamics as simulated by multiple terrestrial biosphere models: Current status and future directions, Global Biogeochem. Cy., 29, 775-792, 2015.

Todd-Brown, K. E. O., Randerson, J. T., Post, W. M., Hoffman, F. M., Tarnocai, C., Schuur, E. A. G., and Allison, S. D.: Causes of variation in soil carbon simulations from CMIP5 Earth system models and comparison with observations, Biogeosciences, 10, 1717-1736, https://doi.org/10.5194/bg-10-1717-2013, 2013.

Torn, M. S., Trumbore, S. E., Chadwick, O. A., Vitousek, P. M., and Hendricks, D. M.: Mineral control of soil organic carbon storage and turnover, Nature, 389, 170-173, 1997.

Torri, D., Poesen, J., and Borselli, L.: Predictability and uncertainty of the soil erodibility factor using a global dataset, Catena, 31, 1-22, 1997.

Trewartha, G. T. and Horn, L. H.: Introduction to climate, 5th Edn., McGraw Hill, New York, NY, 1980.

Trumbore, S. E. and Czimczik, C. I.: An uncertain future for soil carbon, Science, 321, 1455-1456, 2008.

Vet, R., Artz, R. S., Carou, S., Shaw, M., Ro, C. U., Aas, W., and Hou, A.: A global assessment of precipitation chemistry and deposition of sulfur, nitrogen, sea salt, base cations, organic acids, acidity and pH, and phosphorus, Atmos. Environ., 93, 3-100, 2014.

Waite, M. and Sack, L.: Shifts in bryophyte carbon isotope ratio across an elevation $\times$ soil age matrix on Mauna Loa, Hawaii: do bryophytes behave like vascular plants?, Oecologia, 166, 11-22, 2011.

Wang, B., Zheng, F., Römkens, M. J., and Darboux, F.: Soil erodibility for water erosion: A perspective and Chinese experiences, Geomorphology, 187, 1-10, 2013.

Wang, J., Sun, J., Xia, J., He, N., Li, M., and Niu, S.: Soil and vegetation carbon turnover times from tropical to boreal forests, Funct. Ecol., 32, 71-82, 2018.

Weil, R. R. and Brady, N. C.: The nature and properties of soils, Pearson Education, USA, 2016.

Whittaker, R. H.: Classification of natural communities, Bot. Rev., 28, 1-239, 1962.

Wieder, W. R., Bonan, G. B., and Allison, S. D.: Global soil carbon projections are improved by modelling microbial processes, Nat. Clim. Change, 3, 909-912, 2013.

Wiesmeier, M., Barthold, F., Blank, B., and Kögel-Knabner, I.: Digital mapping of soil organic matter stocks using Random Forest modeling in a semi-arid steppe ecosystem, Plant Soil, 340, 7-24, 2011.

Wiesmeier, M., Urbanski, L., Hobley, E., Lang, B., von Luetzow, M., Marin-Spiotta, E., Wesemael, B., Rabot, E., Ließ, M., Garcia-Franco, N., Wollschläger, U., Vogel, H. J., and KögelKnabner, I.: Soil organic carbon storage as a key function of soils-A review of drivers and indicators at various scales, Geoderma, 333, 149-162, 2019. 
Wischmeier, W. H. and Mannering, J. V.: Relation of soil properties to its erodibility, Soil Sci. Soc. Am. J., 33, 131-137, 1969.

Wynn, J. G., Bird, M. I., Vellen, L., Grand-Clement, E., Carter, J., and Berry, S. L.: Continental-scale measurement of the soil organic carbon pool with climatic, edaphic, and biotic controls, Global Biogeochem. Cy., 20, GB1007, https://doi.org/10.1029/2005GB002576, 2006.

$\mathrm{Xu}, \mathrm{T}$. and Hutchinson, M.: ANUCLIM version 6.1 user guide. The Australian National University, Fenner School of Environment and Society, Canberra, Austrialia, 2011.

Yang, Y., Mohammat, A., Feng, J., Zhou, R., and Fang, J.: Storage, patterns and environmental controls of soil organic carbon in China, Biogeochemistry, 84, 131-141, 2007.
Yang, Y., Fang, J., Tang, Y., Ji, C., Zheng, C., He, J., and Zhu, B.: Storage, patterns and controls of soil organic carbon in the Tibetan grasslands, Glob. Change Biol., 14, 1592-1599, 2008.

Yang, Y., Fang, J., Ma, W., Smith, P., Mohammat, A., Wang, S., and Wang, W. E. I.: Soil carbon stock and its changes in northern China's grasslands from 1980s to 2000s, Glob. Change Biol., 16, 3036-3047, 2010.

Yang, Y., Li, P., Ding, J., Zhao, X., Ma, W., Ji, C., and Fang, J.: Increased topsoil carbon stock across China's forests, Glob. Change Biol., 20, 2687-2696, 2014. 